\title{
Identification of the Receptor Subtype Involved in the Analgesic Effect of Neurotensin
}

\author{
Isabelle Dubuc, ${ }^{1}$ Philippe Sarret, ${ }^{2}$ Catherine Labbé-Jullié, ${ }^{2}$ Jean-Marie Botto, ${ }^{2}$ Eric Honoré, ${ }^{2}$ \\ Elisabeth Bourdel, ${ }^{3}$ Jean Martinez, ${ }^{3}$ Jean Costentin, ${ }^{1}$ Jean-Pierre Vincent, ${ }^{2}$ Patrick Kitabgi, ${ }^{2}$ and \\ Jean Mazella² \\ 1 Unité de Neuropsychopharmacologie Expérimentale, Centre National de la Recherche Scientifique (CNRS), 76803 Saint \\ Etienne du Rouvray, France, 2Institut de Pharmacologie Moléculaire et Cellulaire, CNRS, 06560 Valbonne, France, and \\ 3Laboratoire des Aminoacides, Peptides et Protéines, ESA CNRS, Faculté de Pharmacie, Universités de Montpellier 1 et \\ 2, 34060 Montpellier, France.
}

The neuropeptide neurotensin (NT) elicits hypothermic and naloxone-insensitive analgesic responses after brain injection. Recent pharmacological evidence obtained with NT agonists and antagonists suggests that these effects are mediated by a receptor distinct from the initially cloned high-affinity NT receptor (NTR1). The recent cloning of a second NT receptor (NTR2) prompted us to evaluate its role in NT-induced analgesia. Intracerebroventricular injections in mice of two different antisense oligodeoxynucleotides from the NTR2 markedly decreased NTR2 mRNA and protein and reduced NT-induced analgesia.
This effect was specific, because NTR1 levels were unaffected, and sense or scramble oligodeoxynucleotides had no effect. Structure-activity studies revealed a close correlation between the analgesic potency of NT analogs and their affinity for the NTR2 and disclosed potent and selective agonists of this receptor. These data confirm that NTR1 is involved in the NTelicited turning behavior and demonstrate that the NTR2 mediates NT-induced analgesia.

Key words: analgesia; neurotensin; receptor; levocabastinesensitive; oligodeoxynucleotide; antisense
The neuropeptide neurotensin (NT) exerts important central functions, including hypothermic and naloxone-insensitive analgesic responses after brain injection (Al-Rhodan et al., 1991; for review, see Vincent, 1995). NT interacts with two recently cloned receptors that were originally differentiated on the basis of their affinity for NT and their sensitivity to the antihistaminic drug levocabastine (Schotte et al., 1986). The high-affinity, levocabastine-insensitive NT receptor (NTR1) was cloned first (Tanaka et al., 1990; Vita et al., 1993) and shown to mediate a number of peripheral and central NT responses, including the neuroleptic-like effects of the peptide (Labbé-Jullié et al., 1994).

In contrast, the functional relevance of the lower-affinity, levocabastine-sensitive NT receptor (NTR2) cloned later (Chalon et al., 1996; Mazella et al., 1996) remains to be established. Pharmacological evidence suggested that two of the most prominent effects of centrally injected NT i.e., analgesia (Clineschmidt et al., 1979; Nemeroff et al., 1979; Martin and Naruse, 1982; Behbehani and Pert, 1984; Coquerel et al., 1988) and hypothermia (Bissette et al., 1976), were not mediated by the NTR1. Thus, the recently developed nonpeptide NT antagonist SR 48692 (Gully et al., 1993), which preferentially recognizes the NTR1, did not antagonize these effects (Dubuc et al., 1994). Furthermore, a number of metabolically stable peptide and pseudopeptide NT analogs exhibited analgesic and hypothermic potencies that did

Received July 7, 1998; revised Oct. 15, 1998; accepted Oct. 22, 1998.

We thank G. Jarretou and M. Jodar for technical assistance and F. Aguila for photographic work. A special thanks is given to Dr. A. Beaudet for carefully reading this manuscript.

Correspondence should be addressed to Jean Mazella, Institut de Pharmacologie Moléculaire et Cellulaire, Centre National de la Recherche Scientifique, Unité Propre de Recherche 411, 660 Route des Lucioles, 06560 Valbonne, France. Copyright (C) 1998 Society for Neuroscience $\quad 0270-6474 / 98 / 190503-08 \$ 05.00 / 0$ not correlate with their binding affinity for the NTR1 (LabbéJullié et al., 1994).

To investigate a possible role of the NTR2 in mediating NTinduced hypothermia and analgesia, we attempted to selectively block its central expression using in vivo antisense strategies (for review, see Akhtar and Agrawal, 1997). The amount of levocabastine-sensitive NT binding sites and the resulting responses to NT-induced analgesia were specifically decreased in mice intracerebroventricularly injected with specific NTR2 antisense oligodeoxynucleotides (ODNs) compared with control animals injected with solvent, NTR2 sense and scramble ODNs, or with antisense NTR1 ODNs. These results, added to structureactivity studies, identify NTR2 as the receptor that mediates NT-induced analgesia.

\section{MATERIALS AND METHODS}

ODN administration. A first pair of sense and antisense oligodeoxynucleotides (ODN1) was chosen to span the translation start site of the mouse NTR2 (Mazella et al., 1996). Their sequences are as follows: sense, 5'-ATG-GAG-ACC-AGC-AGC-CTG-3'; and antisense, 5'-CAG-GCTGCT-GGT-CTC-CAT- ${ }^{\prime}$. A second pair of phosphorothioate antisense and scramble ODN2 corresponded to nucleotides 30-47 in the coding sequence of NTR2: antisense, 5'-CCT-GCA-CTG-GGG-CTG-GGC-3'; and scramble, 5'-CTC-TCC-GAG-CGG-GTG-GCG-3'. We also synthesized phosphorothioate ODNs spanning the translation start site of the rat NTR1 (Tanaka et al., 1990): antisense, 5'-GGA-GCT-GTT-GAGGTG-CAT-3'; and scramble, 5'-GAG-GTC-TTG-GAG-TGG-ACT-3'. All these ODNs, synthesized by Eurogentec and analyzed by OLIGO 4.0 (National Biosciences, Inc.), were devoid of internal hair loops and putative cross-reactions. In preliminary experiments with ODN1, mice were treated with either a single ODN injection per day for $4 \mathrm{~d}$ or with two ODN injections per day for $3 \mathrm{~d}$, and behavioral tests were performed on the fifth day. There was no change in the hypothermic and analgesic responses to NT in antisense ODN-treated animals compared with control animals. The working conditions then selected for ODN1 were two intracerebroventricular injections (9:00 A.M. and 6:00 P.M.) for 4 


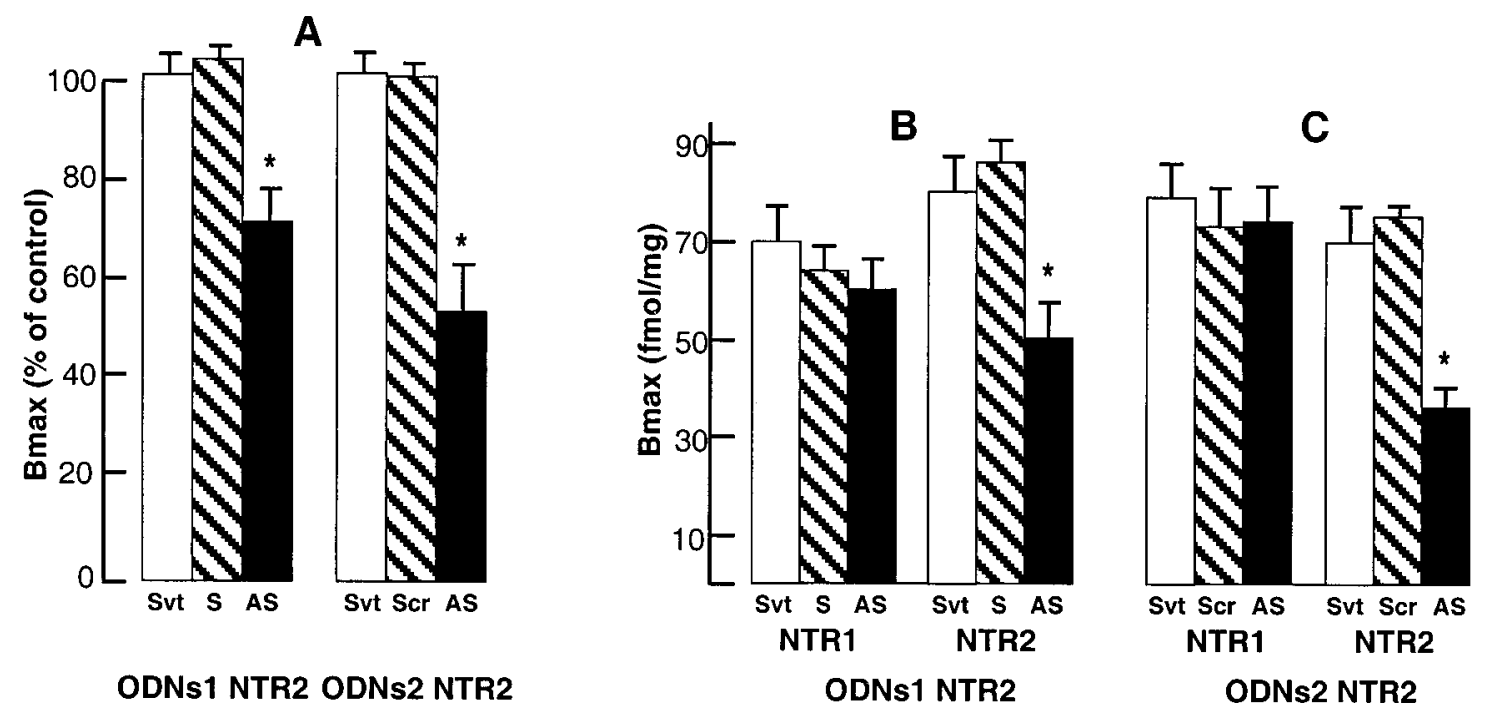

Figure 1. ${ }^{125} \mathrm{I}_{-} \mathrm{Tyr}^{3}-\mathrm{NT}$ binding to homogenates of $\mathrm{CHO}$ cells or mouse brains treated with solvent or ODNs. $A$, Densities $\left(B_{\max }\right)$ of ${ }^{125} \mathrm{I}-\mathrm{Tyr}{ }^{3}-\mathrm{NT}$ binding to membranes from NTR2-expressing CHO cells treated for $3 \mathrm{~d}$ with solvent $(S v t)$, sense $(S)$, scramble $(S c r)$, or antisense $(A S)$ ODN1 NTR2 or ODN2 NTR2. Results are expressed as percentage of $B_{\text {max }}$ values obtained from cells treated with DAC-30 alone $(S v t): 290 \pm 25 \mathrm{fmol} / \mathrm{mg}$ protein $(n=4) . B, C$, Densities $\left(B_{\max }\right)$ of levocabastine-insensitive (NTR1) and levocabastine-sensitive (NTR2) NT receptors in mouse brain homogenates treated with ODN1 NTR2 $(B)$ or ODN2 NTR2 $(C)$. The total and NTR1-specific amount of NT binding sites determined in solvent $(S v t)$, sense $(S)$, or scramble $(S c r)$ ODN-treated mice were similar to those reported previously in mouse brain (Mazella et al., 1988). $B_{\max }$ values were extrapolated from saturation curves fitted with the LIGAND program. Values are mean \pm SEM from two $(A)$ and three $(B, C)$ independent experiments. Data were tested for significance with a Student's $t$ test; * $p<0.01$ compared with solvent-injected mice.

consecutive days, followed by behavioral tests on the fifth day. When unprotected ODN2 (scramble or antisense) was injected according to the latter protocol, no effect on NT-induced responses was observed. It was checked in this case that ODN treatment did not modify the binding of NT to either NTR1 or NTR2. The use of phosphorothioate ODN2 (scramble and antisense) following the same protocol showed some toxicity in the treated mice. The final selected conditions for phosphorothioate ODN2 treatment were two intracerebroventricular injections per day for 3 consecutive days, followed by behavioral tests on the fourth day.

Measurements of biological effects. All drugs were intracerebroventricularly injected in male Swiss CD1 mice (22-24 gm; Charles River, SaintAubin-lès Elbeuf, France) according to the method of Haley and Mc Cormick (1957). All ODNs were injected at $10 \mu \mathrm{l}$ at a dose of $20 \mu \mathrm{g}$ (3.6 nmol). All experimental groups of mice consisted of 10-12 animals. On the test day, NT $(10 \mathrm{ng}=6.7 \mathrm{pmols}$ or $100 \mathrm{ng}=67 \mathrm{pmols})$ or solvent $(7 \%$ saline, $10 \mu \mathrm{l}$ ) was intracerebroventricularly injected. Colonic temperature was measured with a thermistor probe (Thermalert TH5; Physitemp, Clifton, NJ) introduced at a depth of $2 \mathrm{~cm}$ into the rectum, immediately before and $20 \mathrm{~min}$ after the intracerebroventricular injection. Antinociception was determined by the writhing test according to Koster et al. (1959). Writhes were counted over a 15 min period starting from the fifth minute after intraperitoneal injection of a $0.5 \%$ acetic acid solution. The turning behavior was assessed by measuring the number of contralateral rotations induced by $10 \mathrm{pg}$ of unilateral intrastriatal injections of NT as described previously (Gully et al., 1993). Statistical analyses were performed using two-way ANOVA, followed by, when the interaction factor between ODN treatment and NT effect was significant, Dunnett's $t$ tests to assess the significance of the difference between two groups of mice. All procedures were done according to the animal care and handling protocol approved by the Unité de Neuropsychopharmacologie Expérimentale.

ODN treatment of cells. Chinese hamster ovary $(\mathrm{CHO})$ cells stably transfected with the NTR2 as described below were washed twice and incubated in $5 \mathrm{ml}$ of Opti-MEM. ODNs were mixed for $20 \mathrm{~min}$ with DAC-30 (10 $\mu \mathrm{g}$; Eurogentic) in $1 \mathrm{ml}$ of Opti-MEM (Life Technologies, Gaithersburg, MD) and then added drop by drop to cells to give a final concentration of $500 \mathrm{~nm}$. Cells were incubated for $3 \mathrm{hr}$ at $37^{\circ} \mathrm{C}$, and the medium was removed and replaced by the appropriate cell growth medium. ODNs efficiently inhibited NTR2 expression when this treatment was repeated for $3 \mathrm{~d}$, with binding experiments being performed on the fourth day. One day treatment or repeated treatments in the absence of DAC-30 was unable to decrease the amount of bound iodinated NT to membranes from CHO cells expressing the NTR2.

Transfection of $c D N A$ encoding the $m N T R 2$ and binding experiments. The eukaryotic expression vector (pcDNA3) containing the $1.6 \mathrm{~kb}$ EcoRI-ApaI fragment of the NTR2 cDNA was used to transiently transfect COS-7 cells by the DEAE-dextran precipitation method (Cullen, 1987). Stable expression of the NTR2 into CHO cells was obtained by transfection with $5 \mu \mathrm{g}$ of recombinant pcDNA3 vector using $25 \mu \mathrm{g}$ of the cationic liposome DAC-30 (Eurogentec) according to the manufacturer's recommendations. Clonal cell lines were selected by Geneticin (Sigma) $(0.5 \mathrm{mg} / \mathrm{ml})$ and isolated before determination of expression level. The clonal cell line expressing the highest level of NTR2 was selected and used for in vitro experiments.

Binding experiments were performed as described previously (Mazella et al., 1996) using either membranes prepared from brains treated with solvent or ODNs, or homogenates freshly prepared from cells transiently (COS-7) or stably (CHO) transfected with the NTR2. Spinal cord was not analyzed, because this organ primarily contains the inactive variant of NTR2 (Botto et al., 1997b) and because NT analgesic effects are known to be of supraspinal origin (Martin and Naruse, 1982). Homogenates, $50 \mu \mathrm{g}$ of protein from treated cells or $100 \mu \mathrm{g}$ of protein from treated brains, were incubated for $30 \mathrm{~min}$ at $25^{\circ} \mathrm{C}$ with increasing concentrations of ${ }^{125} \mathrm{I}_{-} \mathrm{Tyr}^{3}-\mathrm{NT}(100 \mathrm{Ci} / \mathrm{mmol}, 0.5-15 \mathrm{nM})$ (Sadoul et al., 1984) in the absence or presence of $1 \mu \mathrm{M}$ levocabastine, which selectively inhibits NT binding to the NTR2 (Schotte et al., 1986; Kitabgi et al., 1987).

Electrophysiological measurements. The pcDNA3 vector containing either the cDNA of the mouse NTR2 or the cDNA of the rat NTR1 served as a template to prepare cRNAs using the in vitro transcription kit from Stratagene (La Jolla, CA). cRNAs (10 ng) were injected into Xenopus laevis oocytes. The oocytes were then incubated at $18^{\circ} \mathrm{C}$ for $2-4 \mathrm{~d}$. Electrophysiological measurements were performed at $25^{\circ} \mathrm{C}$ according to the procedure described previously (Botto et al., 1997a). Drugs were applied rapidly into the experimental chamber by a puffer pipette $(200$ $\mu \mathrm{l})$. Responses to drugs were recorded under voltage clamp at $-60 \mathrm{mV}$.

In situ hybridization in mouse brain. The KpnI-Bam HI cDNA fragment (493 bp) corresponding to nucleotides 745-1238 was inserted into the pBluescript KS cloning vector (Stratagene) by PCR and standard cloning techniques and used as a template to produce sense and antisense ${ }^{33} \mathrm{P}$-labeled RNA probes. Mouse brain sections were post-fixed with $4 \%$ paraformaldehyde for $30 \mathrm{~min}$ at room temperature. Sections were incu-

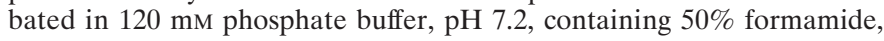


sense
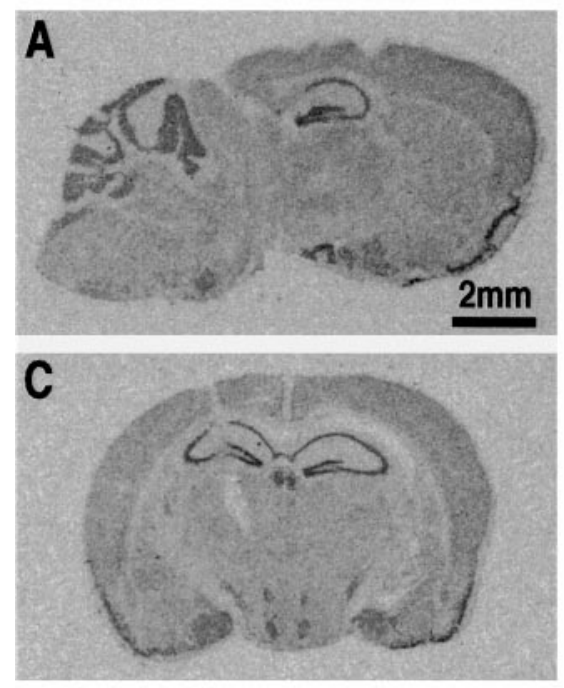

E

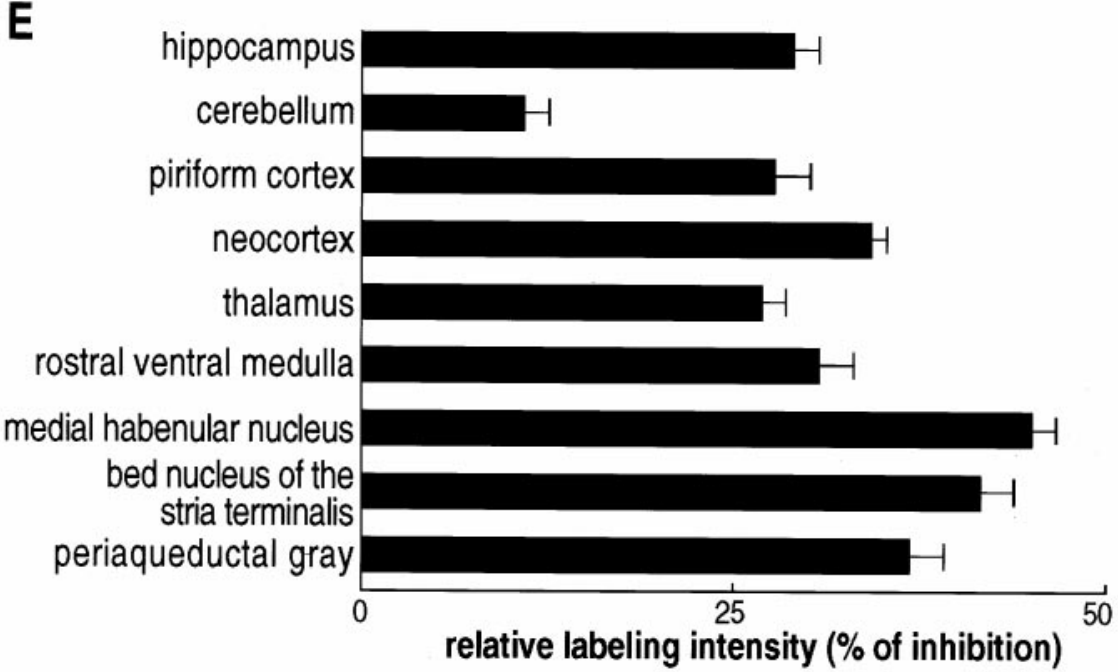

antisense
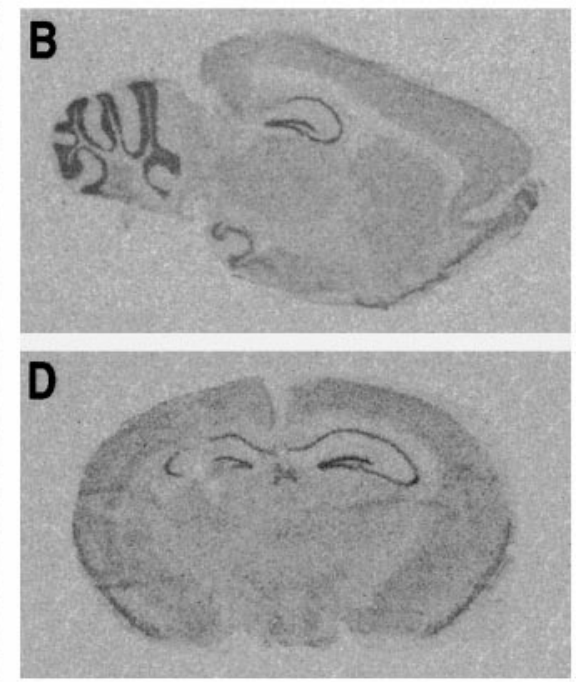

Figure 2. Localization of NTR2 mRNAs in mouse brains treated with sense $(A, C)$ or antisense $(B, D)$ ODN1 NTR2. Sagittal $(A, B)$ or coronal $(C, D)$ sections were hybridized with an antisense ${ }^{33} \mathrm{P}$-labeled cRNA probe corresponding to nucleotides 745-1238 of the mouse NTR2 cDNA (Mazella et al., 1996). Scale bar, $2 \mathrm{~mm}$. E, The decrease in the labeling intensities between sense and antisense ODN-treated mice was measured in various brain areas. Values are mean \pm SEM of optical densities measured on four to six sections from three independent experiments and are expressed as the percentage of decrease between densities measured in brains treated with sense and antisense ODNs. Statistical data were analyzed with the Student's $t$ test. Differences in labeling measured between sense and antisense ODN-treated brains are significant in all regions analyzed; $p<0.001$. Another series of brain sections treated with ODN1 NTR2 were hybridized with ${ }^{33} \mathrm{P}$-labeled ODNs specific of the rat NTR1 (Nicot et al., 1994). No difference was observed in the labeling of both sense or antisense ODN-treated sections (data not shown), indicating that ODN1 treatment specifically decreased the level of NTR2 messengers.
$4 \times$ SSC, $1 \times$ Denhardt's solution, $10 \%$ dextran sulfate, and $0.6 \%$ sarcosyl (Fluka) with sense or antisense ${ }^{33} \mathrm{P}$-labeled RNA probes $\left(3-6 \times 10^{5}\right.$ $\mathrm{cpm} /$ slice). Slices were then washed and processed as described previously (Sarret et al., 1998).

\section{RESULTS}

\section{Effects of ODNs on NT binding in vitro}

The ability of ODN1 and ODN2 to inhibit NTR2 expression was first estimated in vitro in $\mathrm{CHO}$ cells that had been stably transfected with the cDNA encoding the NTR2. When cells were treated for $3 \mathrm{~d}$ with the various ODNs using assisted delivery techniques, treatment with antisense ODN1 and ODN2 resulted in a $30-45 \%$ decrease in NTR2 binding sites measured with ${ }^{125} \mathrm{I}_{-T y r}{ }^{3}$-NT (Fig. $1 A$ ). In contrast, neither sense ODN1 nor scramble ODN2 were able to modify NTR2 binding capacity.

\section{Effect of ODNs on NT binding in vivo}

The two different antisense ODNs and their corresponding sense or scramble ODNs were intracerebroventricularly injected in mice. On the day after the last ODN injection, the density of functional NT receptors was determined on treated brains by measuring ${ }^{125} \mathrm{I}_{-} \mathrm{Tyr}^{3}$-NT binding (Sadoul et al., 1984). Densities of NTR1, corresponding to $B_{\max }$ values of bound ${ }^{125} \mathrm{I}_{-\mathrm{T}} \mathrm{yr}^{3}-\mathrm{NT}$ in the presence of levocabastine, were similar in brain homogenates from all groups of mice (Fig. $1 B, C$ ). Binding to NTR2, defined as the difference between $B_{\max }$ values obtained in the absence and presence of levocabastine, was reduced by $>45 \%$ for antisensetreated mouse brains (Fig. $1 B, C$ ). The affinity of the ligand for both sites was not significantly affected in these different conditions (data not shown). Thus, NTR2 antisense ODNs specifically decreased brain NTR2 expression without modifying NTR1 density (Fig. $1 B, C$ ).

\section{Effects of antisense ODNs on NTR2 mRNA expression}

Next, we investigated the effect of ODN injections on NTR2 mRNA expression by in situ hybridization. Sagittal or coronal slices from brains treated with sense or antisense ODN1 showed labeling of identical regions, including cerebellum, hippocampus, thalamus, neocortex, and piriform cortex (Fig. 2A-D). However, the labeling observed on slices from brains treated with antisense ODN1 (Fig. 2B,D) was significantly reduced compared with the labeling detected on sense ODN1-treated brain slices (Fig. $2 A, C)$. Most of the regions expressing NTR2 mRNA, including thalamic areas, periaqueductal gray, medial habenular nucleus, and bed nucleus of the stria terminalis, displayed a significant reduction in labeling intensity, ranging from 37 to $47 \%$ of the 


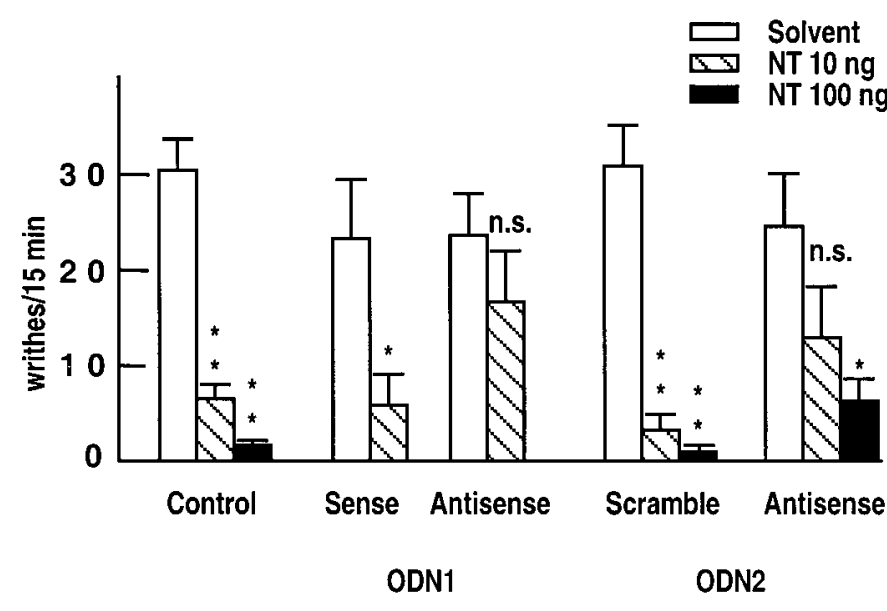

Figure 3. Basal and NT-induced analgesic responses of mice treated with solvent, sense, or antisense ODN1, and scramble or antisense ODN2. Antinociception was assessed by the writhing test. Writhes were counted over a 15 min period after intraperitoneal injection of $0.5 \%$ acetic acid after intracerebroventricular injection of either solvent or 10 or $100 \mathrm{ng}$ of NT. The number of indicated writhes is the mean \pm SEM from groups of 10-12 mice. Two-way ANOVA revealed a positive interaction between ODN treatment and NT analgesic effect. ${ }^{*} p<0.05 ;{ }^{*} p<0.01 ;$ n.s., not significant when compared with groups that received saline injections.

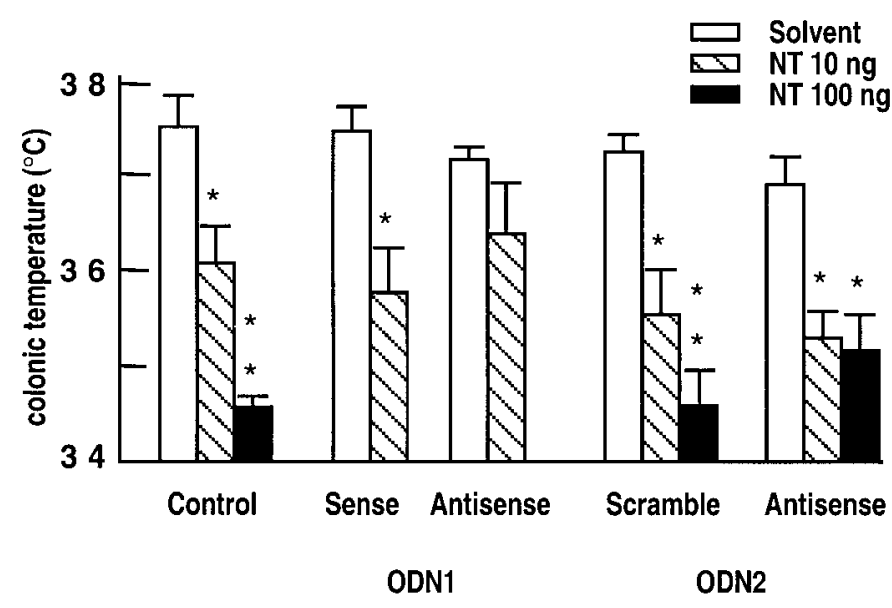

Figure 4. Basal and NT-induced hypothermic responses of mice treated with solvent, sense, or antisense ODN1, and scramble or antisense ODN2. Colonic temperature was measured immediately before or $20 \mathrm{~min}$ after intracerebroventricular injection of 10 or $100 \mathrm{ng}$ of NT. Indicated temperatures are mean \pm SEM from groups of 10-12 mice. Two-way ANOVA showed no interaction between ODN treatment and NT hypothermic effect.

control value (Fig. 2E). In the cerebellum, the decrease of labeling was much less pronounced $(11 \%)$.

\section{Effect of antisense ODN injection on NT-induced analgesia}

Mice injected with NTR2-derived ODNs were subjected to the writhing test used as a means to assess analgesia. The number of writhes/15 min in the absence of NT was similar in solvent-, sense ODN1-, and scramble ODN2-treated mice (control groups), as well as in antisense ODN1- and ODN2-treated mice (Fig. 3). Intracerebroventricular injections of NT (10 ng) significantly decreased the number of writhes in all three control groups (Fig. 3). In contrast, the peptide at $10 \mathrm{ng}$ was without significant effect on the number of writhes in antisense ODN1- and ODN2-treated animals (Fig. 3). This reversal of the NT response observed on the first day after antisense ODN treatment was no longer present on the third day after treatment (data not shown), thus suggesting a rapid clearance of ODNs in mouse brain. When a dose of $100 \mathrm{ng}$ of NT was tested in antisense ODN2-treated mice, a significant analgesic response was obtained, although it was reduced compared with control animals (Fig. 3).

\section{Effect of antisense ODN injection on NT-induced hypothermia}

The effects of antisense ODNs of the NTR2 on the NT-induced hypothermia in mice are shown in Figure 4. Although antisense ODN1 treatment showed a tendency to decrease the response induced by $10 \mathrm{ng}$ of NT (Fig. 4), statistical analysis of the data indicated that the peptide response was not significantly reduced. Antisense ODN2 treatment did not modify the response obtained with $10 \mathrm{ng}$ of NT but decreased, although not significantly, the hypothermia induced by $100 \mathrm{ng}$ of NT (Fig. 4).

\section{Effects of antisense ODNs of NTR1}

As a further control of the specificity of action of NTR2-derived antisense ODNs, mice were treated with scramble and antisense ODNs corresponding to sequence 1-18 of the NTR1 (Tanaka et al., 1990). Binding studies revealed that the levocabastineinsensitive binding component (NTR1) was significantly decreased by $30 \%$ in brain homogenates from antisense-treated mice compared with solvent- and scramble ODN-treated animals, whereas the levels of NTR2 were similar in all three groups of mice (Fig. 5A). The functional consequence of decreased NTR1 expression was assessed on the turning behavior induced in mice by unilateral injections of NT, an effect thought to be mediated via the NTR1, because it is blocked by the selective NTR1 antagonist SR 48692 (Gully et al., 1993; Dubuc et al., 1994). Figure $5 B$ shows that the number of turns induced by unilateral injection of $10 \mathrm{pg}$ of $\mathrm{NT}$ was reduced by $50 \%$ in antisense ODN-treated animals compared with solvent- or scramble ODNtreated mice. This result confirms the involvement of the NTR1 in mediating the turning behavior elicited by NT in mice. We also verified that the antisense ODN2 directed against the NTR2, which had no effect on the amount of NTR1 (Fig. 1), did not affect the turning behavior elicited by NT (Fig. $5 B$ ). Finally, the analgesic and hypothermic responses to NT (10 $\mathrm{ng})$ of mice treated with the NTR1-derived antisense were not affected compared with solvent- or scramble ODN-treated animals (Fig. 6).

\section{Compared potencies of NT analogs for binding to the NTR2 and for inducing analgesia and hypothermia}

We have reported previously on metabolically stable peptide and pseudopeptide analogs of NT whose hypothermic and analgesic potencies did not correlate with their affinity for the NTR1 (Labbé-Jullié et al., 1994). It was therefore of interest to determine their potency for binding to the NTR2 and to compare it with that for inducing analgesia and hypothermia (Table 1). A correlation analysis between the binding and pharmacological potencies of six NT analogs is presented in Figure 7. There was a highly significant correlation $(r=0.96 ; p<0.005)$ between analog potencies for binding to the NTR2 and for inducing analgesia (Fig. 7A). In contrast, the correlation between hypothermia and binding was not statistically significant $(r=0.72)$ (Fig. $7 B)$.

The structure-activity data in Table 1 provide interesting information regarding the selectivity of NT analogs for the NTR2 versus the NTR1. Thus, the potent analgesic analogs Boc$[\Psi 11,12]$ NT- $(8-13)$ and Boc- $\left[\right.$ Lys $\left.^{8-9}, \mathrm{D}-\mathrm{Nal}^{11}\right] \mathrm{NT}-(8-13)$ bind 


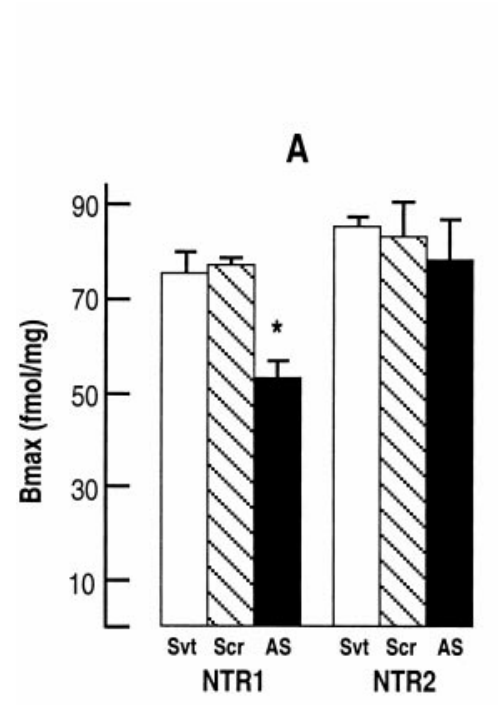

ODNs NTR1

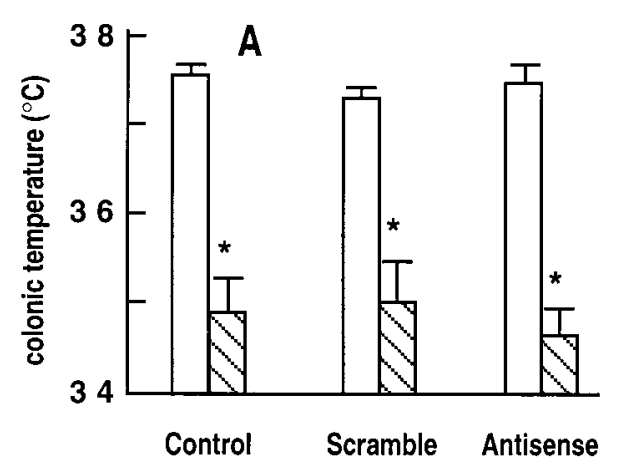

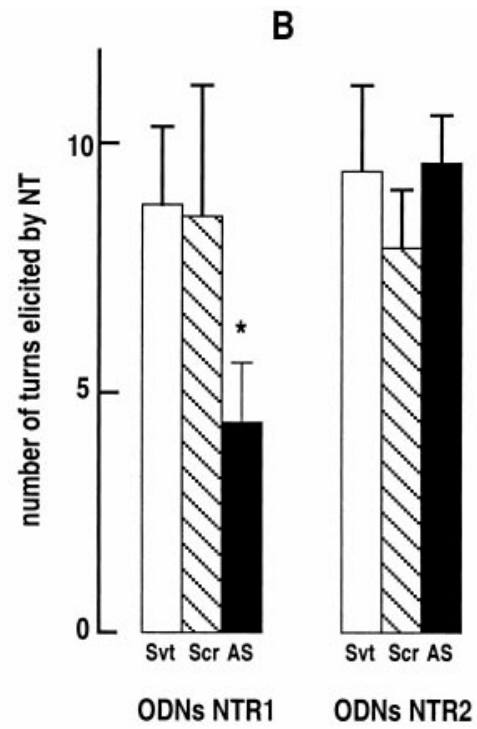

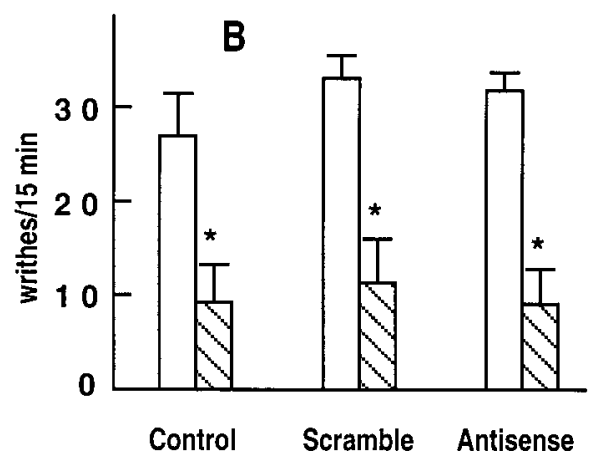

Figure 5. Brain densities of NT receptors and turning behavior of mice treated with NTR1- or NTR2specific ODNs. $A$, Densities $\left(B_{\max }\right)$ of levocabastineinsensitive (NTR1) and levocabastine-sensitive (NTR2) NT receptors in mouse brain homogenates treated with ODN NTR1. $B_{\max }$ values were extrapolated from saturation curves fitted with the LIGAND program. Values are mean \pm SEM from three independent experiments. ${ }^{*} p<0.01$ compared with solvent-injected mice. $B$, The number of contralateral rotations induced by $10 \mathrm{pg}$ of unilateral intrastriatal injections of NT was measured in mice treated with solvent, scramble, or antisense ODNs specific for the NTR1 or NTR2. The number of indicated turns is the mean \pm SEM from groups of 10-12 mice. Two-way ANOVA revealed a positive interaction between ODN NTR1-treatment, but not ODN NTR2treatment, and NT-elicited turns. ${ }^{*} p<0.05$ when compared with groups that received saline injections. $S v t$, Solvent; $S c r$, scramble; $A S$, antisense. mean \pm SEM from groups of $10-12$ mice. ${ }^{*} p<0.01$. Two-way ANOVA showed no interaction between ODN treatment and NT hypothermic and analgesic effects.

Table 1. $K_{\mathrm{i}}$ values for NTR1 and NTR2 and hypothermic and analgesic effects of NT analogs

\begin{tabular}{|c|c|c|c|c|}
\hline Analogs & $\begin{array}{l}\text { rat NTR1 } \\
K_{\mathrm{i}}(\mathrm{nM}) \\
\end{array}$ & $\begin{array}{l}\text { mouse NTR2 } \\
K_{\mathrm{i}}(\mathrm{nM})\end{array}$ & $\begin{array}{l}\text { Hypothermia } \\
\mathrm{D}_{35}(\mathrm{nmol})\end{array}$ & $\begin{array}{l}\text { Analgesia } \\
\mathrm{ED}_{50}(\mathrm{nmol})\end{array}$ \\
\hline (1) Boc-[$\Psi 10,11] \mathrm{NT}-(8-13)$ & $100 \pm 10$ & $65 \pm 11$ & 5.8 & 1.8 \\
\hline (2) Boc- $[\Psi 11,12] \mathrm{NT}-(8-13)$ & $3315 \pm 210$ & $38 \pm 3.3$ & 3.1 & 2.0 \\
\hline (3) Boc-[ $\Psi 12,13] \mathrm{NT}-(8-13)$ & $368 \pm 20$ & $211 \pm 52$ & 33.7 & 4.9 \\
\hline (4) Boc- $\left[\operatorname{Trp}^{11}\right] \mathrm{NT}-(8-13)$ & $0.25 \pm 0.03$ & $1.04 \pm 0.3$ & 0.5 & 0.4 \\
\hline (5) Boc- $\left[\mathrm{Lys}^{8-9}, \mathrm{D}^{8-N a l}{ }^{11}\right] \mathrm{NT}-(8-13)$ & $23,000 \pm 4900$ & $910 \pm 195$ & 12.6 & 21.2 \\
\hline (6) Boc-[Lys $\left.{ }^{8-9}, \mathrm{Nal}^{11}\right] \mathrm{NT}-(8-13)$ & $13 \pm 0.7$ & $215 \pm 58$ & 1.3 & 4.2 \\
\hline
\end{tabular}

Binding potencies of NT analogs, synthesized as reported previously (Doulut et al., 1992), were determined in competition experiments performed with COS-7 cells expressing either the NTR1 or the NTR2 and represent the mean \pm SEM from three independent determinations. Hypothermic potencies $\left(D_{35}\right.$ values corresponding to the dose of analog that brings the mean body temperature to $35^{\circ} \mathrm{C}$ over $\left.4 \mathrm{hr}\right)$ and analgesic potencies $\left(\mathrm{ED}_{50}\right.$ values corresponding to the dose of analog that produces $50 \%$ of the maximal effect) are derived from Labbé-Jullié et al. (1994).

with 90 and 25 times greater affinity to the NTR2 than to the NTR1, respectively. Boc-[ $\Psi 11,12] \mathrm{NT}-(8-13)$ appears therefore as a highly selective ( $\sim 100$-fold) ligand with a relatively good affinity $\left(K_{\mathrm{d}}, \sim 40 \mathrm{nM}\right)$ for the NTR2.

The selectivity of Boc-[ $\Psi 11,12] N T-(8-13)$ was confirmed by experiments performed in Xenopus laevis oocytes injected with either NTR2 or NTR1 cRNAs. Thus, both NT and Boc[ $\Psi 11,12] \mathrm{NT}-(8-13)$ at $1 \mu \mathrm{M}$ elicited similar current responses (250 and $200 \mathrm{nA}$, respectively) in NTR2-expressing oocytes (Fig.

Figure 6. Basal and NT-induced analgesic and hypothermic responses of mice treated with solvent, scramble, or antisense NTR1specific ODNs. $A$, Colonic temperature was measured immediately before or $20 \mathrm{~min}$ after intracerebroventricular injection of 10 $\mathrm{ng}$ of NT. Indicated temperatures are mean \pm SEM from groups of 10-12 mice. ${ }^{*} p<0.01$. B, Antinociception was assessed by the writhing test. Writhes were counted over a 15 min period after intraperitoneal injection of $0.5 \%$ acetic acid after intracerebroventricular injection of solvent (open bars) or $10 \mathrm{ng}$ of NT (hatched bars) The number of indicated writhes is the 
Figure 7. Correlations between binding potencies to the NTR2 and analgesic $(A)$ and hypothermic $(B)$ potencies of NT analogs. All values are derived from Table 1 . Analogs are numbered according to Table 1. The insets show correlation coefficients $(r)$, together with their statistical significance. n.s., Not significant.

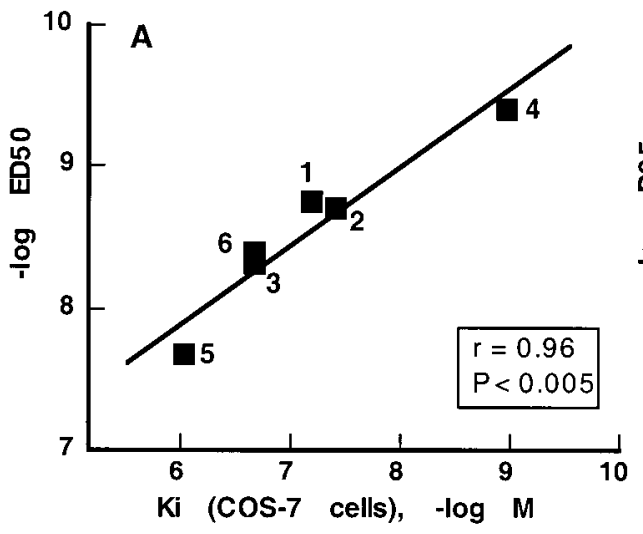

A

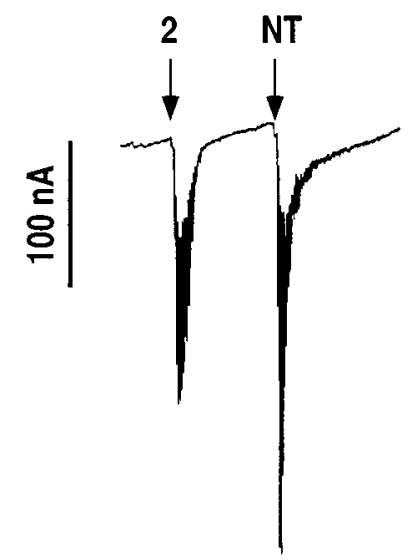

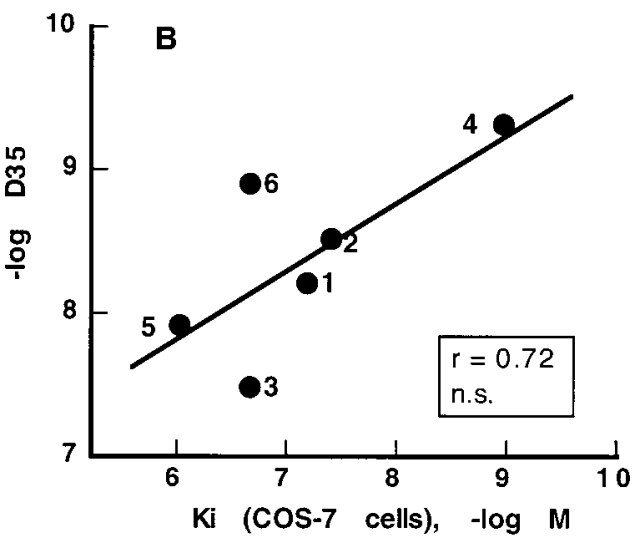

NTR1

B

Figure 8. Current traces recorded from Xenopus oocytes injected with in vitro synthesized NTR2 $(A)$ or NTR1 $(B)$ mRNA. Downward deflections induced by application of $1 \mu \mathrm{M}$ NT or Boc-[ $\Psi 11,12]$ NT-(8-13) (analog 2 in Table 1$)$ indicate $\mathrm{Ca}^{2+}$-activated $\mathrm{Cl}^{-}$currents.

expression of the NTR2 and to show that this decrease was accompanied by a reduction in the analgesic response elicited by NT. In addition, we found that the potencies of NT analogs for binding to the NTR2 correlated well with their potency for inducing analgesia.

Such strategies have been successfully used by many groups to reveal a variety of receptor functions. For example, intracerebroventricular injections of antisense ODNs directed against the anxiolytic neuropeptide Y-Y1 receptor selectively reduced its cerebral expression in the rat and produced anxiogenic-like effects (Wahlestedt et al., 1993a). An identical approach performed on the NMDA-R1 receptor channel protected cortical neurons from NMDA excitotoxicity and reduced focal ischemic infarctions (Wahlestedt et al., 1993b).

The validity of ODNs used in this work was first assessed on CHO cells stably transfected with NTR2 in which repeated treatments for $3 \mathrm{~d}$ with NTR2-specific antisense ODNs led to a $35-40 \%$ decrease in receptor expression. Then, conditions were selected for the in vivo treatment of mice with ODNs. These conditions led to a selective decrease of NTR2 expression in the brain and to a significant reduction in the analgesic response to NT. It should be noted that while looking for working conditions for in vivo ODN treatment, a number of preliminary experiments failed to alter NT-induced analgesia. In all such experiments, postmortem NT binding experiments showed no change in the brain levels of NTR2. Conversely, in all experiments in which antisense ODNs decreased the NT analgesic response there was a concomitant reduction in NTR2 brain levels. The specificity of action of the chosen antisense ODNs is further supported by a number of observations. First, the reduction in NTR2 binding sites and the decrease in NT-induced analgesia were obtained with two different sets of antisense ODNs against the NTR2, whereas their sense or scramble counterparts were devoid of effect. Second, the decrease in NT binding in the brain of treated mice resulted from a selective decrease in NTR2 binding capacity, with no change in the capacity of NTR1. Third, ODNs against the NTR1 were without effect on NTR2 binding capacity and NT-induced analgesia, whereas they decreased 
the number of NTR1 binding sites. Finally, the turning behavior elicited by NT was reduced in NTR1 antisense ODN-treated mice, whereas it was unaffected in NTR2 antisense ODN2treated animals. It is important to stress that although phosphorothioate ODNs often produce nonspecific effects when injected into the brain of rodents, such nonspecific effects were not observed in this study, because, for example, ODNs did not affect body temperature per se.

The loss of NTR2 binding measured after antisense ODN injections could be the consequence of both the inhibition of mRNA translation by antisense ODNs and the decrease of NTR2 mRNAs level in brains of antisense-treated animals (Fig. 2). This latter observation is usually explained by the action of RNase-H, which degrades the RNA strand of an RNA-DNA duplex (Phillips and Gyurko, 1995). It is interesting to note that brain areas identified previously as being involved in NT-induced analgesia (Behbehani, 1992) correspond to regions, such as the periaqueductal gray, in which the expression of NTR2 mRNAs is the most affected by antisense ODN treatment.

NTR2 antisense ODN administration in mice did not totally block the analgesic response to NT. In particular, the animals were still partly responsive to a $100 \mathrm{ng}$ dose of peptide. This suggests that the blockade of NT-induced analgesia was not the consequence of a toxic effect of the ODNs. Actually, the apparent loss of NT potency is consistent with the fact that ODN treatment partially decreased the number of NTR2s available for NT binding in mouse brain, and that, therefore, a higher dose of peptide was needed for recruiting the number of NTR2s that must be activated to trigger the analgesic response.

The binding potencies of a series of metabolically stable peptide and pseudopeptide NT analogs toward the NTR2 correlated well with their potencies to induce analgesia. These pharmacological data provide additional evidence that the NTR2 is involved in NT-induced analgesia. One of the tested pseudopeptide NT analogs, Boc-[ $\Psi 11,12]$ NT-(8-13), showed a rather good affinity for the NTR2 $\left(K_{\mathrm{d}}, 40 \mathrm{nM}\right)$ and a high selectivity (100-fold) for the NTR2 over the NTR1. The selectivity was confirmed by showing that the pseudopeptide elicited a 25-fold greater response in NTR2-expressing oocytes than NTR1-expressing oocytes. Together, these binding and functional data suggest that Boc-[ $\Psi 11,12]$ NT- $(8-13)$ might represent the starting point for the development of a selective, high-affinity agonist ligand of the NTR2.

Although NTR2 antisense ODN treatment tended to decrease the NT-induced hypothermia, statistical analysis of the data revealed that this effect was not significant. This could suggest either that a NT receptor different from the NTR1 and NTR2 subserves the hypothermic effect of the peptide or that ODNs were unable to induce a functionally significant reduction of NTR2 levels in those brain regions involved in NT-mediated hypothermia. Structure-activity data indicated that there was no significant correlation between the binding potency and that for inducing hypothermia. In particular, two analogs, Boc$[\Psi 12,13] \mathrm{NT}-(8-13)$ and Boc-[ $\left.\mathrm{Lys}^{8-9}, \mathrm{Nal}^{11}\right] \mathrm{NT}-(8-13)$, which exhibited equipotency for binding to the NTR2 and inducing analgesia, differed by a factor of 25 in their potencies for inducing hypothermia (Table 1). This would support the hypothesis that the NT hypothermic response is mediated through a receptor distinct from the NTR2. In a recent study, Tyler et al. (1998a) reported on NT analogs that showed markedly different potencies in their ability to induce hypothermia and analgesia. This again lends support to the idea that NT elicits hypothermia through an as yet unidentified receptor subtype. Interestingly, a third NT receptor whose role is not yet elucidated has been recently cloned (Mazella et al., 1998).

In conclusion, the antisense ODN strategy used here has proven to be a useful approach to assess the functional relevance of the NTR2 in the absence of selective antagonist. Our results strongly argue that the NTR2 is directly involved in the expression of NT-induced analgesia. In contrast, the results suggest, in agreement with others (Tyler et al., 1998b), that NT-induced hypothermia is mediated through an as yet unidentified NT receptor subtype. Finally, the results identify agonists that are potent and selective for the NTR2. Altogether, this should make it feasible, using drug screening and/or rational design strategies, to develop NTR2 agonists that may pass the blood-brain barrier and act as potent nonopioid analgesics. If the analgesic effect of NT is demonstrated in humans and if this effect is mediated by NTR2, such compounds could be useful for the treatment of pain.

\section{REFERENCES}

Akhtar S, Agrawal S (1997) In vivo studies with antisense oligonucleotides. Trends Pharmacol Sci 18:12-18.

Al-Rhodan NRF, Richelson E, Gilbert JA, McCormick DJ, Kanba KS, Pfenning MA, Nelson A, Larson EW, Yaksh TL (1991) Structureantinociceptive activity of neurotensin and some novel analogues in the periaqueductal gray region of the brainstem. Brain Res 557:227-235.

Behbehani MM (1992) Physiological mechanisms of the analgesic effect of neurotensin. Ann NY Acad Sci 668:253-265.

Behbehani MM, Pert A (1984) A mechanism for the analgesic effect of neurotensin as revealed by behavioural and electrophysiological techniques. Brain Res 324:35-47.

Bissette G, Nemeroff CB, Loosen PT, Prange AJ, Lipton MA (1976) Hypothermia and intolerance to cold induced by intracisternal administration of the hypothalamic peptide neurotensin. Nature 262:607-609.

Botto JM, Guillemare E, Vincent JP, Mazella J (1997a) Effects of SR48692 on neurotensin-induced calcium-activated chloride currents in the Xenopus oocyte expression system. Agonist-like activity on the levocabastine-sensitive neurotensin receptor and absence of antagonist effect on the levocabastine-insensitive neurotensin receptor. Neurosci Lett 223:193-196.

Botto JM, Sarret P, Vincent JP, Mazella J (1997b) Identification and expression of a variant isoform of the levocabastine-sensitive neurotensin receptor in the mouse central nervous system. FEBS Lett 400:211-214.

Chalon P, Vita N, Kaghad M, Guillemot M, Bonnin J, Delpech B, Lefur G, Ferrara P, Caput D (1996) Molecular cloning of a levocabastinesensitive neurotensin binding site. FEBS Lett 386:91-94.

Clineschmidt BV, McGuffin JC, Bunting PB (1979) Neurotensin: antinocisponsive action in rodents. Eur J Pharmacol 54:129-139.

Coquerel A, Dubuc I, Kitabgi P, Costentin J (1988) Potentiation by thiorphan and bestatin of the naloxone-insensitive analgesic effects of neurotensin and neuromedin N. Neurochem Int 12:361-366.

Cullen BR (1987) Use of eukaryotic expression technology in the functional analysis of cloned genes. Methods Enzymol 152:684-704.

Doulut S, Rodriguez M, Lugrin D, Vecchini F, Kitabgi P, Aumelas A, Martinez J (1992) Reduced peptide bond pseudopeptide analogues of neurotensin. Pept Res 5:30-38.

Dubuc I, Costentin J, Terranova JP, Barnouin MC, Soubrié P, Lefur G, Rostène W, Kitabgi P (1994) The nonpeptide neurotensin antagonist, SR48692, used as a tool to reveal putative neurotensin receptor subtypes. Br J Pharmacol 112:352-354.

Gully D, Canton M, Boigegrain R, Jeanjean F, Molimard JC, Poncelet M, Gueudet C, Heaulme M, Leyris R, Brouard A, Pélaprat D, LabbéJullié C, Mazella J, Soubrié P, Maffrand JP, Rostène W, Kitabgi P, Le Fur G (1993) Biochemical and pharmacological profile of a potent and selective nonpeptide antagonist of neurotensin receptor. Proc Natl Acad Sci USA 90:65-69.

Haley TJ, Mc Cormick WG (1957) Pharmacological effects produced by intracerebral injection of drugs in the conscious mouse. Br J Pharmacol 12:12-15. 
Kitabgi P, Rostène W, Dussaillant M, Schotte A, Laduron PM, Vincent JP (1987) Two populations of neurotensin binding sites in murine brain: discrimination by the antihistamine levocabastine reveals markedly different radioautographic distribution. Eur J Pharmacol 140:285-293.

Koster R, Anderson M, De Beer EJ (1959) Acetic acid for analgesic screening. Fed Proc 18:412-415.

Labbé-Jullié C, Dubuc I, Brouard A, Doulut S, Bourdel E, Pelaprat D, Mazella J, Martinez J, Rostène W, Costentin J, Kitabgi P (1994) In vivo and in vitro structure-activity studies with peptide and pseudopeptide neurotensin analogs suggest the existence of distinct central neurotensin receptor subtypes. J Pharmacol Exp Ther 268:328-336.

Martin GE, Naruse T (1982) Differences in the pharmacological actions of intrathecally administered neurotensin and morphine. Regul Pept 3:97-103.

Mazella J, Chabry J, Kitabgi P, Vincent JP (1988) Solubilization and characterization of active neurotensin receptors from mouse brain. J Biol Chem 263:144-149.

Mazella J, Botto JM, Guillemare E, Coppola T, Sarret P, Vincent, JP (1996) Structure, functional expression, and cerebral localization of the levocabastine-sensitive neurotensin/neuromedin $\mathrm{N}$ receptor from mouse brain. J Neurosci 16:5613-5620.

Mazella J, Zsürger N, Navarro V, Chabry J, Kaghad M, Caput D, Ferrara P, Vita P, Gully D, Maffrand JP, Vincent JP (1998) The $100 \mathrm{kDa}$ neurotensin receptor is gp95/sortilin, a non-G-protein-coupled receptor. J Biol Chem 273:26273-26276.

Nemeroff CB, Osbahr III AJ, Manberg PJ, Erwin GN, Prange AMJ (1979) Alteration in nociception and body temperature after intracisternal administration of neurotensin, $\beta$-endorphine, other endogenous peptides and morphine. Proc Natl Acad Sci USA 76:5368-5371.

Nicot A, Rostène W, Bérod A (1994) Neurotensin receptor expression in the rat forebrain and midbrain: a combined analysis by in situ hybridization and receptor autoradiography. J Comp Neurol 341:407-419.
Phillips MI, Gyurko R (1995) In vivo applications of antisense oligonucleotides for peptide research. Regul Pept 59:131-141.

Sadoul JL, Mazella J, Kitabgi P, Vincent JP (1984) Preparation of neurotensin selectively iodinated on the tyrosine 3 residue: biological activity and binding properties on mammalian neurotensin receptors. Biochem Biophys Res Commun 120:812-819.

Sarret P, Beaudet A, Vincent JP, Mazella J (1998) Regional and cellular distribution of low affinity neurotensin receptor mRNA in adult and developing mouse brain. J Comp Neurol 394:344-356.

Schotte A, Leysen JE, Laduron PM (1986) Evidence for a displaceable non-specific ${ }^{3} \mathrm{H}$-neurotensin binding sites in rat brain. Naunyn Schmiedebergs Arch Pharmacol 333:400-405.

Tanaka K, Masu M, Nakanishi S (1990) Structure and functional expression of the cloned rat neurotensin receptor. Neuron 4:847-854.

Tyler BM, Cusack B, Douglas CL, Souder T, Richelson E (1998a) Evidence for additional neurotensin receptor subtypes: neurotensin analogs that distinguish between neurotensin-mediated hypothermia and antinociception. Brain Res 792:246-252.

Tyler BM, McCormick DJ, Hoshall CV, Douglas CL, Jansen K, Lacy BW, Cusack B, Richelson E (1998b) Specific gene blockade shows that peptide nucleic acids readily enter neuronal cells in vivo. FEBS Lett 421:280-284.

Vincent JP (1995) Neurotensin receptors: binding properties, transduction pathways, and structure. Cell Mol Neurobiol 15:501-512.

Vita N, Laurent P, Lefort S, Chalon P, Dumont X, Kaghad M, Gully D, Le Fur G, Ferrara P, Caput D (1993) Cloning and expression of a complementary DNA encoding a high affinity human neurotensin receptor. FEBS Lett 317:139-142.

Wahlestedt C, Golanov E, Yamamoto S, Yee F, Ericson H, Yoo H, Inturrisi CE, Reis DJ (1993a) Antisense oligodeoxynucleotides to NMDA-R1 receptor channel protect cortical neurons from excitotoxicity and reduce focal ischaemic infarctions. Nature 363:260-263.

Wahlestedt C, Pich EM, Koob GF, Yee F, Heilig M (1993b) Modulation of anxiety and neuropeptide Y-Y1 receptors by antisense oligodeoxynucleotides. Science 259:528-531. 